\title{
Community Based Tourism dalam Pengelolaan Desa Wisata Giriloyo, Wukirsari, Imogiri, Bantul
}

\author{
Suwarjo \\ Prodi Ilmu Administrasi Negara Fakultas Ilmu Sosial dan Ilmu Politik \\ Universitas Widya Mataram \\ jojoaufa@gmail.com
}

\begin{abstract}
The results of study showed that community-based community in Giriloyo Tourism Village can be used for all community of batik artisans community who joined in paguyuban batik. Community agility from the stages of planning, evaporation, to activities. Forum meetings from hamlet level, batik community to tourist village become a forum for the community to convey aspirations and campaigns-inspiring activities.

To motivate the community in Giriloyo Tourism Village, the following suggestions are offered: 1) the need for optimization of community meeting vessels to explore the potentials of interest for batik. Special tours special outbound and traditional culinary; 2) to increase the interest of the young generation of batik handicrafts in Giriloyo Tourism Village, can organize annual event with batik and staining pattern creations. Competition can be done in groups and there is no relationship that can be established relationships and close cooperation between adolescents.
\end{abstract}

Keywords : community based tourism

\section{Pendahuluan}

Pendekatan yang menempatkan masyarakat sebagai bagian yang tidak terpisahkan dari produk wisata dan pemahaman bahwa produk wisata merupakan proses rekayasa sosial masyarakat merupakan esensi dari pembangunan berbasis pada komunitas (Community Based Development). Arah lebih jauhnya adalah terwujudnya pemberdayaan ekonomi masyarakat desa melalui berbagai aktivitas ekonomi yang berkembang untuk menunjang potensi wisata yang dimiliki. (Suwarjo, 2016).

Pengembangan desa wisata berbasis pada komunitas atau masyarakat (community based tourism) merupakan satu langkah yang dapat menunjang keberlanjutan pengelolaan sebuah desa wisata. Hasil riset Andini (2013) menunjukkan pentingnya pengorganisasian komunitas dalam pengembangan agrowisata mulai dari tahap integrasi, pemetaan isu, potensi dan permasalahan, perancangan tindakan bersama, implementasi hingga feedback terkait pengembangan desa wisata. 
Desa Wisata Giriloyo adalah salah satu desa wisata di Kabupaten Bantul dengan keunikan produk kerajinan batik tulis yang sudah lama dikenal. Pengembangan Desa Wisata Giriloyo saat ini bukan tanpa hambatan sekaligus tantangan di masa depan terkait dengan regenerasi keahlian batik tulis pada generasi muda. Generasi muda yang cenderung enggan terjun di usaha kerajinan batik tulis menjadi kendala dalam pewarisan keahlian. Pelibatan komunitas dalam setiap kegiatan layanan wisata sangat diperlukan. Keterlibatan segenap anggota komunitas dalam perencanaan hingga pelaksanan kegiatan layanan wisata akan mampu meningkatkan partisipasi komunitas yang semakin baik sekaligus akan meringankan beban kolektif. Adanya sharing manfaat juga akan diperoleh bersama. Kelemahan dalam pengembangan Desa Wisata Giriloyo, peneliti melihat belum adanya pengorganisasian komunitas dalam berbagai kegiatan layanan wisata.

Uraian sekilas di atas, menarik dikaji tentang pengembangan desa wisata yang berbasis community based tourism di Desa Wisata Giriloyo. Kajian akan fokus pada pola pengelolaan komunitas dalam setiap kegiatan organisasi kolektif desa wisata, keterlibatan komunitas dalam proses perencanaan dan pelaksanaan kegiatan layanan wisata dan strategi pewarisan keahlian batik tulis kepada generasi muda.

\section{Tinjauan Pustaka}

\section{A. Desa Wisata dan Pengelolaannya}

Desa wisata dalam dekade terakhir ini telah menjadi wacana menarik dalam mencari alternatif dari pengembangan pariwisata konvensional. Desa wisata yang merupakan pengembangan dari rural tourism, farm tourism, atau village tourism, membawa visi dan misi yang jelas, sebagai remedy terhadap berbagai hambatan yang ada selama ini. Di sisi lain, pengembangan desa wisata ini menjadi alternatif sensitif, karena jika salah dalam perencanaan maupun pengelolaannya, dapat menimbulkan dampak buruk terhadap keberadaan Desa Pekraman dimana desa wisata itu dikembangkan (Pitana, 1999: 105).

Desa wisata sebagai suatu produk wisata yang melibatkan anggota masyarakat desa dengan segala perangkat yang dimilikinya. Desa wisata tidak hanya berpengaruh pada ekonominya, tetapi juga sekaligus dapat melestarikan lingkungan alam dan sosial budaya masyarakat terutama berkaitan dengan nilai-nilai kebersamaan, kekeluargaan, kegotongroyongan, dan lain-lain. Kelestarian alam dan sosial budaya masyarakat akan menjadi daya tarik bagi wisatawan yang melakukan perjalanan wisata. (Muljadi, 2009: 27).

Ditjenpar (1999) dalam Arlini (2003) mendefinisikan desa wisata sebagai suatu wilayah perdesaan yang menawarkan keseluruhan suasana yang mencerminkan keaslian pedesaan, arsitektur bangunan dan tata ruang desa, serta mempunyai potensi untuk dikembangkan berbagai komponen kepariwisataan, misalnya atraksi wisata makanan dan minuman, cinderamata, penginapan, dan kebutuhan lainnya. 
B. Pengelolaan Desa Wisata Berbasis Community Based Tourism

Pengembangan desa wisata semestinya menerapkan pendekatan community based tourism. Dalam posisi demikian masyarakat berperan penting dalam menunjang pembangunan pariwisata.

Sedangkan keterlibatan pemerintah dan swasta sebatas memfasilitasi masyarakat sebagai pelaku utama pengembangan desa wisata. "Pariwisata dari rakyat, oleh rakyat dan untuk rakyat" adalah jargon produk masa pemerintahan Gus Dur yang diproduksi untuk menunjukkan perhatian dan dorongan pemerintah kepada masyarakat dalam membangun kepariwisataan. Nilai-nilai yang mendasari tidak lain adalah bahwa pariwisata yang dijalankan pemerintah selama ini sudah semestinya memang benar-benar bisa memberikan peran total bagi masyarakat yang ujungnya bermuara pada kesejahteraan rakyat. Sesuai dengan hakekat desa wisata yang semestinya diinisiasi secara intern dan mandiri oleh masyarakat tempatan (lokal) ini berarti bahwa pemerintah, baik tingkat pusat dan daerah hanya sebagai fasilitator. Proses tumbuh dan berkembangnya desa wisata akan bergantung pada masyarakat itu sendiri. (Raharjana, 2010).

Pigram (1993) dalam Raharjana (2005) mengatakan bahwa pengembangan desa wisata merupakan suatu bentuk pengembangan wilayah desa yang lebih cenderung pada penggalian potensi desa dengan memanfaatkan unsur-unsur yang ada dalam desa sebagai atribut produk wisata. Kelahiran sebuah kegiatan wisata perdesaan sepatutnya memperhatikan, melibatkan, dan memberikan peran yang proporsional kepada masyarakat setempat selaku pemilik sah dari lingkungan perdesaan. Peran serta masyarakat baik dusun maupun desa setempat sangat penting, terkait dengan dasar dan arah pengembangan desa wisata.

Masyarakat lokal sebagai bagian integral dari suatu desa wisata yang berperan, baik sebagai subyek yang berkaitan langsung dengan pengembangan desa wisata. Upaya pengembangan desa wisata berbasis komunitas, peran serta masyarakat dalam proses perencanaan hingga penarikan manfaat atau keuntungan atas pelaksanaan kegiatan menempati posisi yang penting.

Menurut Anonim (1995) pariwisata yang bertumpu pada masyarakat (community based tourism) bertujuan untuk:

1. Memajukan tingkat hidup masyarakat dan sekaligus melestarikan identitas serta tradisi lokal.

2. Meningkatkan pendapatan secara ekonomis dan sekaligus mendistribusikan pada masyarakat lokal.

3. Berorientasi pada pengembangan wirausaha berskala kecil dan menengah dengan daya serap tenaga kerja besar dan berorientasi pada teknologi tepat guna.

4. Mengembangkan semangat kerja sama sekaligus kompetisi.

5. Kepemilikan bersama aset dan sumber pariwisata dengan anggota masyarakat. 
6. Memanfaatkan pariwisata seoptimal mungkin sebagai agen penunjang tradisi budaya.

Pengembangan desa wisata berbasis komunitas memiliki peluang besar untuk meraih keberhasilan. Namun pencapaian tujuan tersebut bukan hal yang mudah dan tanpa tantangan. Masalah yang cukup berat adalah membangun pemahaman dan pengertian kepada masyarakat desa bahwa keikutsertaan dan peran serta langsung mereka memiliki andil yang besar dalam pengembangan desa wisata. Kebersamaan dan keterlibatan aktif semua komponen dalam desa wisata sangat menentukan eksistensi desa wisata di masa mendatang.

\section{Kerangka Pemikiran}

Pengembangan desa wisata berbasis community based tourism membutuhkan peran aktif masyarakat yang berada di desa bersangkutan. Keterlibatan aktif masyarakat dapat tercipta ketika mereka memahami maksud dan tujuan pengembangan desa wisata sekaligus memiliki kepercayaan bahwa manfaat ekonomi dapat diperoleh sebagai hasil dari berbagai kegiatan yang dilakukan. Berikut ini skema kerangka pemikiran dalam penelitian ini:

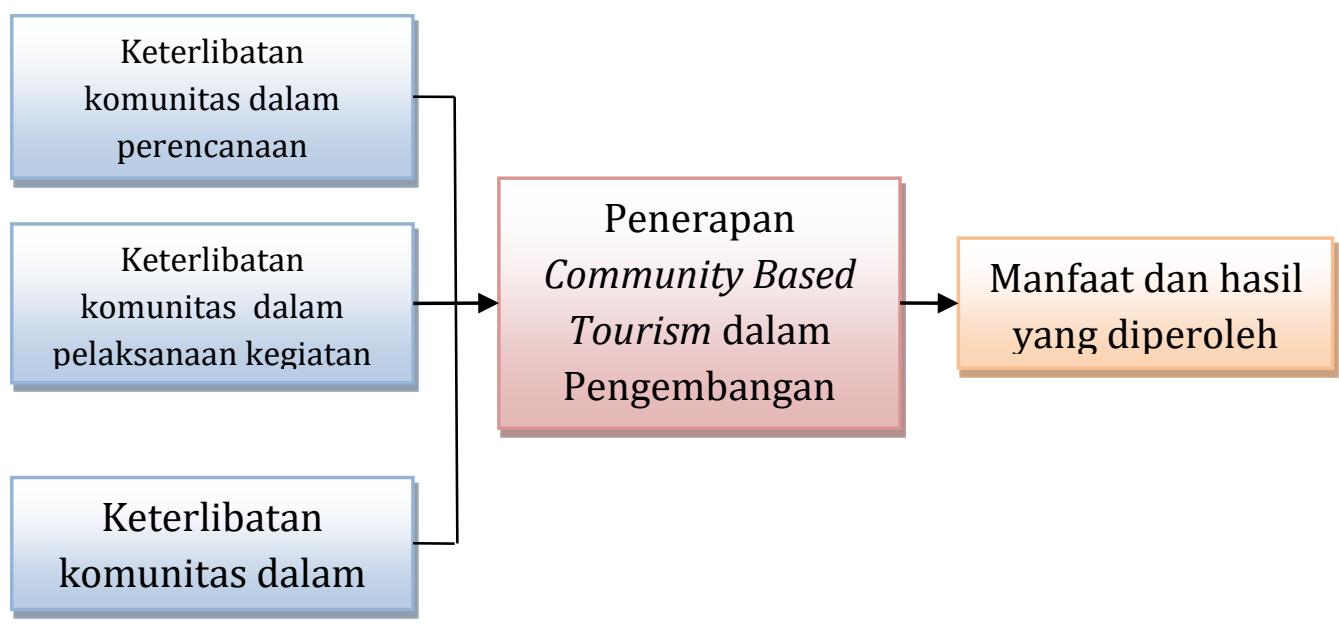

Metode penelitian

Penelitian ini merupakan penelitian deskriptif yang dimaksudkan untuk mengungkap dan mengkaji strategi pengelolaan desa wisata Giriloyo yang berbasis community based tourism. Penggalian data primer dilakukan melalui indepth interview, FGD terbatas dan pengamatan langsung serta dokumentasi.
Sedangkan sumber data sekunder yaitu data yang diperoleh secara tidak langsung dari obyeknya, tetapi melalui sumber-sumber lain secara lisan maupun tulisan. Informan yang dipilih dalam penelitian ini adalah pihak-pihak yang dianggap tahu dan memahami persoalan yang diteliti diantaranya : 1) Pengurus paguyuban batik Giriloyo; 2) Pengurus Desa Wisata 
Giriloyo; 3) Dinas Pariwisata Kabupaten Bantul; dan masyarakat

Hasil dan pembahasan

Pasca gempa bumi 2006 yang melanda wilayah DIY dan Jawa Tengah, merupakan momentum kebangkitan Desa Wisata Giriloyo. Peristiwa gempa bumi tersebut membawa berkah dalam bentuk kepedulian banyak pihak terhadap kondisi Dusun Giriloyo dengan keahlian khas batik tulis. Perhatian pemerintah maupun swasta untuk kembali membangkitkan kerajinan batik Giriloyo semakin meningkat. Hadirnya sebuah organisasi swasta yaitu Jogja Heritage Sociaty (JHS) yang bekerjasama dengan Australian Indonesian Partnership menginisiasi pembentukan wadah bagi para pengrajin batik di Dusun Giriloyo. Wadah pengrajin batik dalam bentuk paguyuban (kelompok). Wadah paguyuban terus bertambah seiring dengan waktu dan antusias warga masyarakat untuk memiliki wadah aktivitas mereka. Peran berbagai organisasi swasta dan pemerintah menjadi sangat penting dalam menentukan positioning masyarakat pengrajin batik di Desa Wisata Giriloyo.

\section{Keterlibatan komunitas dalam perencanaan program}

Pengelolaan desa wisata berbasis komunitas (community based tourism) sangat memerlukan keterlibatan seluruh elemen masyarakat yang ada. Keterlibatan anggota komunitas dalam kegiatan pengelolaan desa wisata dimulai dari partisipasinya dalam kegiatan perencanaan program-program desa wisata. Keterlibatan dalam proses perencanaan progam akan sangat menentukan keterlibatan mereka dalam proses berikutnya yaitu partisipasi aktif dalam pelaksanaan program yang telah direncanakan.

Keterlibatan aktif komunitas pengrajin batik Giriloyo dalan menunjang kegiatan Desa Wisata Giriloyo diwujudkan dalam aktifitas pertemuan paguyuban pengrajin batik. Pada akhir tahun 2006 pasca gempa bumi, wadah paguyuban pengrajin batik baru terbentuk 4 (empat) paguyuban yaitu Sungging Tumpuk, Sekar Arum, Sido Mukti dan Sekar Kedaton, hingga pada tahun 2007 sudah berkembang menjadi 12 (dua belas) paguyuban. Bahkan pada tahun 2018 sudah terbentuk 15 (lima belas) kelompok. Berikut ini nama paguyuban batik tulis Giriloyo dan jumlah anggotanya : 
Tabel 1

Nama Paguyuban Batik Tulis Giriloyo, Ketua dan Jumlah Anggota

\begin{tabular}{|c|l|c|l|}
\hline No & \multicolumn{1}{|c|}{ Nama Paguyuban } & Jumlah anggota & \multicolumn{1}{|c|}{ Ketua } \\
\hline 1 & Sido Mukti & 26 & Martini \\
\hline 2 & Suka Maju & 91 & Yazinah \\
\hline 3 & Giri Indah & 21 & Rosni Wahidah \\
\hline 4 & Sekar Arum & 34 & Nur Ahmadi \\
\hline 5 & Sekar Kedaton & 15 & Jazir Hamid \\
\hline 6 & Sungging Tumpuk & 10 & Amiroh \\
\hline 7 & Sungsang Batik & 20 & Sonaji \\
\hline 8 & Sri Kuncoro & 20 & Imaroh \\
\hline 9 & Songgo Langit & 11 & Nuriyah \\
\hline 10 & Pinggir Gunung & 17 & Nurjanah \\
\hline 11 & Bima Sakti & 15 & Hartinah \\
\hline 12 & Sari Sumekar & 21 & Suyamti \\
\hline 13 & Fajar Batik & 13 & Siti Wahadah \\
\hline 14 & Berkah Lestari & 40 & Erni Purwanti \\
\hline 15 & Kusumo Batik & 18 & Ismail \\
\hline
\end{tabular}

Sumber : Dokumentasi Desa Wisata Giriloyo, 2018

Sebagian nama paguyuban batik tulis di Desa Wisata Giriloyo diambil dari nama corak batik yang menjadi kekhasan produk paguyuban tersebut. Misalnya paguyuban batik tulis Sido Mukti, anggota paguyuban tersebut hanya memproduksi batik dengan corak sido mukti. Paguyuban lain yang identik dengan kekhasan corak batik yang dihasilkan adalah Sri Kuncoro, Songgo Langit, Sekar Arum, Sekar Kedaton, Sungging Tumpuk, Giri Indah, Pinggir Gunung dan Sungsang Batik.

Sebagian paguyuban lainya, produk batiknya tidak mencerminkan corak batik yang dihasilkan seperti Paguyuban Berkah Lestari dan Fajar Batik. Meski demikian, paguyuban tersebut juga memiliki kekhasan produk batik tulis yang dihasilkan. Kekhasan produk batik yang dihasilkan masing-masing paguyuban merupakan hasil kreatifitas anggota paguyuban. Untuk mewadahi berbagai kegiatan yang terselenggara yang ada dan minat kunjungan masyarakat dalam dan luar D.I Yogyakarta yang meningkat di Desa Wisata Giriloyo maka diinisiasi untuk membentuk organisasi Desa Wisata Giriloyo. Berikut ini struktur organisasi pengurus Desa Wisata Giriloyo : 


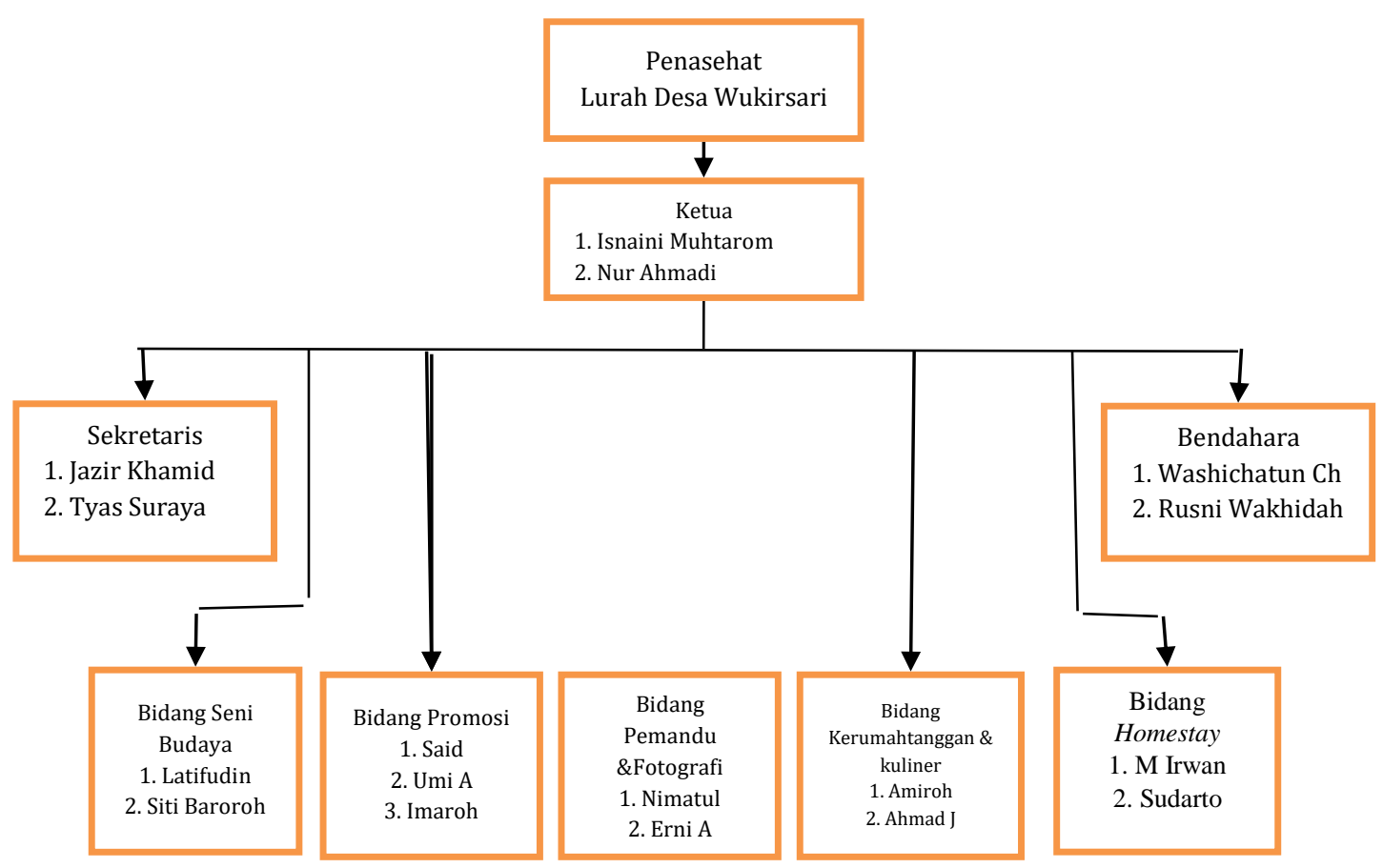

Sumber : Dokumen Desa Wisata Giriloyo, 2018.

Seiring dengan meningkatnya jumlah kunjungan wisatawan ke Desa Wisata Giriloyo dengan berbagai tuntutan layanan yang diperlukan, keterlibatan komunitas masyarakat terutama para pengrajin batik sangat dibutuhkan. Kunjungan wisata yang meningkat terutama kunjungan untuk tujuan studi banding dan belajar membatik memerlukan pengorganisasian kegiatan. Untuk menunjang layanan setiap kunjungan wisata, dilakukan perencanaan kegiatan penerimaan tamu. Berikut pembagian tugas penerimaan kunjungan wisata secara garis besarnya : 
Tabel 2

\section{Pembagian Tugas Penerimaan Kunjungan Wisata}

\begin{tabular}{|c|l|c|}
\hline No & \multicolumn{1}{|c|}{ Pembagian Tugas } & Pelaksana /personil \\
\hline 1 & Penerima tamu & Bergilir \\
\hline 2 & Presentasi sejarah Desa Wisata Giriloyo & Bergilir \\
\hline 3 & Konsumsi dan akomodasi & Kelompok bergantian \\
\hline 4 & Pendampingan belajar membatik & Anggota dari paguyuban \\
\hline 5 & Petugas pelayanan showroom batik & Anggota dari paguyuban \\
\hline 6 & Petugas parkir & Bergilir \\
\hline
\end{tabular}

Sumber : Olah data hasil wawancara pengurus Desa Wisata Giriloyo, 2018

Pembagian tugas dalam penerimaan kunjungan tamu tersebut dimaksudkan untuk membangun keterlibatan semua anggota komunitas dalam kegiatan Desa Wisata Giriloyo. Pemerataan pembagian tugas penerimaan kunjungan wisata terutama pada tugas penyiapan komsumsi dan pendampingan belajar membatik. Untuk tugas penyiapan konsumsi dibentuk kelompok-kelompok yang terdiri 5 hingga 6 orang. Pembagian tugasnya diatur sedemikian rupa sehingga semua kelompok mendapatkan tugas merata dalam setiap bulannya. Demikian juga untuk tugas pendampingan belajar membatik, personil pendamping berasal dari anggota-anggota paguyuban batik yang memiliki waktu dan berminat untuk melakukan pendampingan. Sedangkan untuk pembagian tugas layanan showroom batik, untuk saat ini dilakukan oleh anggota paguyuban yang memajang produk batiknya. Bagi paguyuban yang tidak memajang produk batiknya di showroom, tidak menyediakan personil untuk layanan showroom batik.
Selain perencanaan kegiatan penerimaan tamu, kegiatan-kegiatan lainnya yang diperlukan juga direncanakan seperti kegiatan pelatihan-pelatihan bagi pengrajin batik dan upaya pelestarian kerajinan batik tulis melalui pewarisan kepada generasi muda. Kegiatan pelatihan yang direncanakan tersebut diajukan kepada instansi terkait seperti Dinas Koperasi UKM dan Perindustrian Kabupaten Bantul.

Uraian tentang keterlibatan komunitas dalam perencanaan kegiatan di Desa Wisata Giriloyo di atas memperlihatkan telah adanya sinergi dan kerjasama yang terjalin baik di antara anggota komunitas maupun dengan pengurus Desa Wisata Giriloyo. Keterlibatan aktif angggota komunitas cukup berhasil menumbuhkan rasa memiliki atas kegiatankegiatan desa wisata yang diselenggarakan.

\section{Keterlibatan komunitas dalam} pelaksanaan kegiatan

Perwujudan Community Based Tourism dalam pengelolaan Desa Wisata Giriloyo ditunjukkan dari adanya keterlibatan aktif segenap anggota komunitas dalam setiap 
Suwarjo, Community Based Tourism dalam ...

kegiatan yang diselenggarakan. Keikutsertaan masyarakat dalam proses perencanaan kegiatan dilanjutkan dalam pelaksanaan kegiatan bersama. Berbagai wadah perkumpulan warga masyarakat yang ada mulai dari wadah perkumpulan di tingkat Rukun Tetangga (RT), paguyuban batik, Dusun hingga organisasi Desa Wisata Giriloyo menjadi sarana penyampaian ide gagasan dan saran bagi kebaikan bersama. Wadah perkumpulan tersebut dianggap efektif untuk memecahkan berbagai permasalahan bersama yang sedang dihadapi. Pembahasan permasalahan pada wadah perkumpulan tersebut erat terkait dengan kebutuhan dan tuntutan yang sedang maupun yang akan dihadapi ke depan. Berikut beberapa bahasan pada masing-masing organisasi perkumpulan di Desa Wisata Giriloyo : 
Tabel 3

Topik Bahasan pada Organisasi Perkumpulan di Desa Wisata Giriloyo

\begin{tabular}{|c|c|c|}
\hline No & Wadah Organisasi & Kegiatan dan Topik Bahasan yang sering diangkat \\
\hline 1 & RT dan RW & $\begin{array}{ll}\checkmark & \text { Arisan } \\
\checkmark & \text { Kelancaran pelaksanaan ronda lingkungan } \\
\checkmark & \text { Sosialisasi program-program pemerintah } \\
\checkmark & \text { Evaluasi kegiatan yang telah dilaksanakan } \\
\checkmark & \text { Pembahasan usul dan saran warga } \\
\checkmark & \text { Pembahasan kegiatan yang akan dilaksanakan }\end{array}$ \\
\hline 2 & $\begin{array}{l}\text { Karang Taruna } \\
\text { Dusun }\end{array}$ & $\begin{array}{ll}\checkmark & \text { Arisan } \\
\checkmark & \text { Penyampaian laporan pengurus } \\
\checkmark & \text { Evaluasi kegiatan yang telah dilaksanakan } \\
\checkmark & \text { Pembahasan kegiatan yang akan dilaksanakan } \\
\checkmark & \text { Pembahasan usulan anggota }\end{array}$ \\
\hline 3 & Paguyuban Batik & $\begin{array}{ll}\checkmark & \text { Arisan } \\
\checkmark & \text { Penyampaian laporan pengurus paguyuban } \\
\checkmark & \text { Sosialisasi program pelatihan dari pemerintah } \\
\checkmark & \text { Membahas usulan anggota paguyuban }\end{array}$ \\
\hline 4 & Dusun & $\begin{array}{ll}\checkmark & \text { Penyampaian laporan keuangan dusun } \\
\checkmark & \text { Sosialisasi program-program pemerintah } \\
\checkmark & \text { Evaluasi kegiatan yang telah dilaksanakan } \\
\checkmark & \text { Pembahasan usul dan saran dari warga } \\
\checkmark & \text { Pembahasan kegiatan yang akan dilaksanakan }\end{array}$ \\
\hline 5 & Desa Wisata & $\begin{array}{ll}\checkmark & \text { Penyampaian laporan pengurus termasuk } \\
& \text { laporan keuangan } \\
\checkmark & \text { Pembahasan usulan dan masukan anggota } \\
\checkmark & \text { Evaluasi kegiatan yang telah dilaksanakan } \\
\checkmark & \text { Pembagian tugas penerimaan tamu kunjungan } \\
\checkmark & \text { Pembahasan kegiatan yang akan dilaksanakan } \\
& \text { dan pembagian tugasnya }\end{array}$ \\
\hline
\end{tabular}

Sumber : Olah data hasil wawancara, April 2018. 
Frekuensi pertemuan masing-masing wadah perkumpulan tersebut adalah selapan (36 hari). Namun dalam situasi yang memerlukan pemecahan masalah ataupun persetujuan warga masyarakat, pertemuan tidak rutin bisa diselenggarakan. Pertemuan tidak rutin yang sering melakukan adalah organisasi desa wisata. Pertemuan tersebut dilakukan untuk membahas dan membagi tugas layanan kunjungan wisata.

Seiring dengan semakin dikenalnya Desa Wisata Giriloyo di masyarakat luas, frekuensi kunjungan tamu juga semakin meningkat. Hampir di asetiap hari libur nasional, hari sabtu dan Minggu ada kunjungan tamu wisata dalam jumlah besar. Keterlibatan komunitas dalam setiap kegiatan penerimaan tamu wisata dalam jumlah besar sangat dibutuhkan. Dibutuhkan jumlah tenaga yang cukup banyak terutama untuk memberikan pendampingan belajar membatik dan penyediaan konsumsi. Adanya pembagian tugas layanan kunjungan wisata secara merata di antara paguyuban batik dan masyarakat menjadi dasar terbangunnya kebersamaan dan pemerataan pendapatan. Selama ini penerimaan tamu kunjungan wisata di Desa Wisata Giriloyo dipusatkan di kompleks Kampung Batik Giriloyo.

Keberadaan Kompleks Kampung Batik Giriloyo pada awalnya terwujud atas dukungan berbagai pihak. Berikut ini pihak-pihak yang mendukung fasilitas di Komplek Kampung Batik Giriloyo:

Tabel 4

\section{Fasilitas Bangunan di Kompleks Kampung Batik Giriloyo dan Pihak yang Membantu}

\begin{tabular}{|l|l|}
\hline \multicolumn{1}{|c|}{ Nama Fasilitas } & \multicolumn{1}{c|}{ Pihak yang membantu } \\
\hline Tanah Kampung Batik Giriloyo & $\begin{array}{l}\text { Pemerintah Desa Wukirsari (Tanah kas } \\
\text { Desa) }\end{array}$ \\
\hline Bangunan Joglo utama & LSM IRE \\
\hline Bangunan Showroom batik dan Gazebo & $\begin{array}{l}\text { Dinas Koperasi, UKM dan } \\
\text { Perindustrian Kab. Bantul }\end{array}$ \\
\hline Fasilitas Toilet & BUMN Pertamina \\
\hline Pagar keliling & Dinas Pariwisata Kab. Bantul \\
\hline
\end{tabular}

Sumber : Olah data wawancara, 2018

Sejak adanya Kompleks Kampung Batik Giriloyo, penerimaan tamu kunjungan wisata dipusatkan di kompleks tersebut. Jumlah kunjungan wisata dari waktu ke waktu terus mengalami peningkatan hingga sekarang.
Pengurus Desa Wisata Giriloyo memberikan ruang kesempatan yang luas bagi anggotaanggota paguyuban batik untuk terlibat dalam layanan tamu. Pada akhirnya setelah melalui proses panjang dari usulan paguyuban- 
paguyuban batik dibentuklah kelompokkelompok pendamping belajar membatik. Sekaligus juga dilakukan penjadwalan tugas pendampingan belajar membatik. Kunjungan tamu yang tidak dapat diprediksikan, dibuatlah sarana informasi melalui media sosial sehingga memudahkan untuk koordinasi.

Keterlibatan segenap komunitas dalam pengelolaan Desa Wisata Giriloyo merupakan bagian penting dari penerapan community based tourism. Bahkan tanpa adanya keterlibatan komunitas dalam aktivitas Desa Wisata Giriloyo akan sangat sulit berjalan. Adanya sharing tugas dan pendapatan dari aktivitas layanan wisata yang diselenggarakan merupakan bentuk konkrit dari penerapan community based tourism.

Berbagai kegiatan lain yang dilaksanakan oleh paguyuban-paguyuban batik di bawah naungan organisasi Desa Wisata Giriloyo telah dirasakan memberikan manfaat kepada para anggota paguyuban. Adanya Kompleks Kampung Batik Giriloyo yang di area tersebut tersedia bangunan showroom batik dapat dimanfaatkan untuk etalase produk sekaligus promosi produk serta penjualan hasil kerajinan batik dari paguyuban. Manfaat langsung yang dapat diterima oleh anggota paguyuban yang terlibat dalam kegiatan layanan tamu adalah manfaat ekonomi berupa upah jasa lelah.

Manfaat lain yang diperoleh dengan adanya kunjungan tamu yang terus meningkat adalah terbukanya kesempatan mengenalkan dan memasarkan produk lokal masyarakat setempat seperti teh gurah, wedang uwoh dan kuliner dengan bahan-bahan lokal yang disuguhkan sebagai bagian dari paket layanan wisata seperti sayuran lokal untuk menu makanan yang disediakan. Warga masyarakat diberikan kesempatan untuk menawarkan suplai bahan lokal untuk menu kuliner sajian wisata dan produk lokal lainnya yang dapat dipajang di Kompleks Kampung Batik Giriloyo. Upaya pelestarian ketrampilan batik yang dimiliki oleh masyarakat di Desa Wisata Giriloyo juga menjadi perhatian bersama. Di tengah perubahan gaya hidup generasi muda saat ini, upaya pewarisan ketrampilan batik bukan tanpa menghadapi tantangan. Kecenderungan sebagian generasi muda kurang berminat menekuni ketrampilan membatik telah mulai nampak. Terdapat pandangan sebagian generasi muda bahwa aktivitas membatik kurang memberikan prospek cerah di masa depan.

Usaha pewarisan ketrampilan membatik kepada generasi muda, paguyuban-paguyuban batik mulai menyadari pentingnya upaya pewarisan yang direncanakan. Salah satunya adalah menyelenggarakan aktivitas membatik di sanggar-sanggar paguyuban pada hari libur. Penyediaan insentif (upah) atas hasil kerja anakanak muda disiapkan. Termasuk penyiapan peralatan dan bahan-bahan membatik sehingga anak-anak muda tidak perlu repot untuk menyiapkan sebelumnya.

\section{Keterlibatan komunitas dalam pelaksanaan evaluasi kegiatan \\ Pengembangan pariwisata berbasis komunitas (community based tourism)}


memerlukan keterlibatan aktif masyarakat mulai dari perencanaan kegiatan hingga melakukan evaluasi atas pelaksanaan kegiatan. Evaluasi menjadi aktivitas yang sangat penting agar diperoleh penilaian kinerja kegiatan yang telah dilakukan sekaligus mendapatkan masukan yang berharga dalam proses penyusunan kegiatan di kemudian hari.

$$
\text { Pelaksanaan evaluasi kegiatan }
$$

pengelolaan Desa Wisata Giriloyo dilakukan secara rutin melalui kegiatan pertemuan rutin maupun tidak rutin yang diselenggarakan. Pertemuan rutin diselenggarakan setiap selapanan (36 hari) dengan dihadiri oleh pengurus Desa Wisata Giriloyo dan perwakilan paguyuban dan tokoh masyarakat. Agenda dalam pertemuan rutin selapan hari tersebut, evaluasi pelaksanaan kegiatan-kegiatan yang berjalan menjadi topik bahasan utama selain melakukan perencanaan kegiatan yang akan dikerjakan ke depan. Sedangkan pertemuan tidak rutin diselenggarakan ketika akan ada kunjungan tamu wisata dalam jumlah banyak. Pembahasan persiapan penerimaan kunjungan tamu menjadi agenda utama pada setiap pertemuan selain pembahasan evaluasi layanan tamu sebelumnya.

Salah satu hasil evaluasi kegiatan yang melibatkan komunitas paguyuban batik yang ada di Desa Wisata Giriloyo adalah munculnya gagasan untuk membuat kelompok pendamping belajar membatik dari anggota-anggota paguyuban batik yang ada. Munculnya gagasan tersebut seiring dengan meningkatnya jumlah kunjungan tamu. Selain dapat meningkatkan layanan wisata, pelibatan lebih banyak anggota komunitas paguyuban batik dimaksudkan untuk pemerataan peran dan manfaat langsung dari aktivitas pendampingan belajar membatik.

Pelayanan wisata Desa Wisata Giriloyo sampai saat ini masih belum meluas pada penyediaan layanan homestay. Kunjungan wisata masih sebatas untuk keperluan studi banding dan belajar membatik. Permintaan kunjungan wisata untuk menginap di Desa Wisata Giriloyo hingga saat ini belum ada. Wacana dan gagasan pengembangan wisata yang lebih menarik sebenarnya sudah pernah dibahas dalam pertemuan rutin, namun tindak lanjutnya masih belum direalisasikan. Gagasan lain yang disampaikan adalah wacana menciptakan wisata outbond. Gagasan pengembangan wisata outbond sebenarnya sangat didukung oleh kondisi alam pegunungan yang menarik dan memiliki kekhasan alam pegunungan yang segar. Sampai saat ini, langkah-langkah untuk mewujudkan gagasan tersebut belum sepenuhnya mendapat dukungan segenap komunitas. Pertimbangan diperlukannya pembiayaan yang besar, pelayanan kunjungan tamu wisata untuk studi banding dan belajar membatik dirasakan pengurus Desa Wisata Giriloyo telah menyita banyak waktu dan tenaga.

\section{Kesimpulan}

Pengelolaan pariwisata berbasis komunitas (community based tourism) di Desa Wisata Giriloyo menunjukkan suatu fakta bahwa 
keterlibatan aktif komunitas dalam setiap kegiatan baik perencanaan, pelaksanaan dan evaluasi kegiatan menjadi kekuatan utama bagi keberlangsungan kegiatan dan eksistensi desa wisata.

Pelestarian kerajinan batik tulis pada generasi muda merupakan tantangan yang tidak ringan untuk dihadapi. Di tengah perkembangan ekonomi yang meningkat, berpengaruh pada banyaknya pilihan lapangan pekerjaan di luar kerajinan membatik. Strategi pelestarian kerajinan batik untuk membangkitkan minat remaja menekuni batik tulis melalui insentif "uang jajan" dan penyediaan peralatan membatik "siap pakai" di beberapa sanggar paguyuban, terlihat cukup berhasil. Tidak sedikit remaja (perempuan) yang memanfaatkan waktu luang setelah pulang sekolah atau di waktu libur, melakukan aktivitas membatik di sanggarsanggar paguyuban. Dorongan masing-masing remaja melakukan aktivitas membatik di waktu luang cukup beragam, diantaranya adalah keinginan untuk melestarikan batik tulis khas Giriloyo, membantu orang tua, dapat berkumpul bersama dengan teman-temannya hingga keinginan mendapatkan "uang jajan".

Pengelolaan wisata berbasis komunitas (community based tourism) di Desa Wisata Giriloyo saat ini masih memerlukan dukungan agar dapat berjalan lebih baik sehingga beberapa saran masukan yang ditawarkan diantaranya :

1. Perlunya peran dan kontribusi konkrit dari Pemerintah Daerah Kabupaten Bantul dalam memberikan pendampingan dan membantu penggalian potensi wisata lokal yang menarik dikembangkan selain kerajinan batik. Penyediaan sarana outbond yang digagas oleh komunitas di Desa Wisata Giriloyo dapat diwujudkan dengan adanya bantuan dan pendampingan dari Pemerintah Daerah Kabupaten Bantul;

2. Penyelenggaraan even-even di tingkat Kabupaten Bantul dapat menjadi ajang pengenalan potensi wisata dari banyak desa wisata yang ada di wilayah Kabupaten Bantul. Selain itu. Dengan ajang even pameran desa wisata, dapat menjadi informasi dan referensi masyarakat luas ketika memilih lokasi kunjungan wisata.

3. Untuk meningkatkan minat generasi muda terhadap kerajinan batik di Desa Wisata Giriloyo, dapat diselenggarakan even tahunan kompetisi kreasi pola batik dan pewarnaan. Kompetisi tersebut bisa dilakukan secara berkelompok sehingga selain mendapatkan manfaat belajar membatik juga terjalin hubungan dan kerjasama yang erat antar remaja;

4. Diperlukan upaya eksplorasi potensi kuliner tradisional yang lebih variatif sebagai bagian dari layanan kunjungan wisata ke Desa Wisata Giriloyo. Dengan kunjungan wisata yang terus meningkat, peluang pengenalan produk kuliner lokal tradisional sangat terbuka. Baik makanan olahan siap saji maupun 
Suwarjo, Community Based Tourism dalam ...

makanan olahan dalam kemasan.

Harapannya upaya pengembangan

kuliner lokal dapat mendongkrak geliat

ekonomi perdesaan dan peningkatan

pendapatan masyarakat.

\section{Daftar Pustaka}

Anonim. 1995. Laporan Akhir Studi Pengembangan Wisata Minat Khusus (Tak dipublikasikan). Yogyakarta: Dinas Pariwisata DI Yogyakarta dan Pusat Penelitian dan Pengembangan Pariwisata (PUSPAR) UGM

Andini, Nurulitha. 2012, Pengorganisasian Komunitas dalam Pengembangan Agrowisata di Desa Wisata Kembangarum., [Online].
Didapatkan:

http://nurulithaandini.wordpress.com/a uthor/nurulithaandini/html[23Oktober 2012].

Arlini, Wike Pramudya. 2003. Analisis Efektifitas Promosi Desa Wisata Candirejo Magelang Jawa Tengah. Jakarta : Jurusan Usaha Perjalanan Wisata Sekolah Tinggi Pariwisata TRISAKTI

Muljadi, A.J. 2009. Kepariwisataan dan Perjalanan. Jakarta: PT. Rajagrafindo Persada.

Pitana, I. Gede. 1999. Pelangi Pariwisata Bali. Denpasar: Bali Post. 